\title{
APLIKASI MESIN PEMBANGKIT KALOR LAS LPG UNTUK POTONG, PENYAMBUNGAN DAN PEMBENTUKAN
}

\section{APPLICATION OF WELDING-LPG HEAT GENERATION MACHINE FOR CUTTING, WELD JOINT AND FORMING}

\author{
${ }^{1)}$ Seno Darmanto, ${ }^{2)}$ Indartono, ${ }^{3)}$ Adi Nugroho \\ ${ }^{1)}$ Program D IV Teknik Mesin, Sekolah Vokasi Universitas Diponegoro \\ ${ }^{2)}$ Program D III Teknik Mesin, Sekolah Vokasi Universitas Diponegoro \\ ${ }^{3)}$ JurusanKomunikasi, Fakultas Ilmu Sosial dan Ilmu Politik, Universitas Diponegoro, \\ Jln Prof. Soedarto SH, Tembalang Semarang Jawa Tengah \\ email : senodarmanto@gmail.com
}

\begin{abstract}
ABSTRAK
Kegiatan pengabdian dilakukan di industri ukir tembaga dan kuningan Zazen Art Galeri. Keberadaan industri ukir tembaga dan kuningan di Kelurahan Mliwis Cepogo memberikan potensi yang besar terutama di bidang ekonomi, sosial, pendidikan dan lapangan kerja.vPermasalahan produk ukir dengan desain rumit dan ukuran relative besar masih menjadi kendala dan perlu tambahan pengerjaanmeliputi pengerolan, pembentukan, pengelasan dan penyelesaian akhir.Tujuan kegiatan ini adalah modifikasi instalasi mesin pembangkit kalor untuk pengerjaan pemanasan, potong, menyambung dan membentuk lengkung pada pipa dan plat. Modifikasi pengelasan LPG dilakukan dengan merekayasa las asetilin dengan beberapa komponen yakni tabung oksigen dan katup pengaturan (regulator oksigen), tabung LPG dan katup pengaturan (regulator LPG), selangan distribusi gas (oksigen dan gas LPG), alat ukur tekanan dan injektor nyala las. Hasil pengujian menunjukkan bahwa las LPG dapat diterapkan untuk pemotongan dan penyambungan plat dengan ketebalan di bawah 0,6 $\mathrm{mm}$. Selanjutnya tungku berbahan bakar arang dapat diaplikasikan untuk pemanasan plat tebal dengan ketebalan di atas $1 \mathrm{~mm}$.
\end{abstract}

Kata kunci: Ukir, Tembaga, Kuningan, Tungku, Pengelasan.

\begin{abstract}
The existence of copper and brass carving industry in Mliwis Cepogo Sub-district gives great potential especially in economic, social, education and employment field. Carving brass and copper industries also provide support for nature and agro tourism in the slopes of Mount Merapi and Merbabu, especially the nature attractions of the Selo mountains. The challenge of carving products with complicated designs and large relative sizes is still a major problem and need extra processing namely rolling, forming, welding and finishing. Objectives to be achieved in the application of technology through Science and Technology Program for the Community is a modification of heat generation machine type for heating, cutting work, connecting and forming curves on pipes and plates. Themodification of LPG welding is carried out by modifying the acetylene welding by several components ie oxygen tube and regulatory valve (oxygen regulator), LPG tube and regulatory valve (LPG regulator), gas distribution (oxygen and LPG), pressure gauges and welding injectors. The test results show that LPG welding can be applied for cutting and plate connection with thickness below $0.6 \mathrm{~mm}$. Next, charcoal-fired furnaces can be applied for heating thick plates with thickness above $1 \mathrm{~mm}$.
\end{abstract}

Keywords : Carving, Copper, Brass, Furnace, Welding 
Seno Darmanto, Indartono, Adi Nugroho

Aplikasi Mesin Pembangkit Kalor Las Lpg Untuk Potong, Penyambungan Dan Pembentukan

Submitted : 5 Februari 2018 Revision: 24 Juni 2018 Accepted : 25 Juni 2018

\section{PENDAHULUAN}

Industri Ukir Tembaga dan Kuningan Zazen Art Galeria merupakan salah satu industri tembaga dan kuningan yang masih eksis di Kelurahan Mliwis Cepogo Boyolali. Produk utama Industri Ukir Tembaga dan Kuningan Zazen Art Galeria adalah benda/perabotukir (accessories) tembaga dan kuningan untuk rumah tangga.System produksi menerapkan pola produksi masal dan juga permintaan/pesanan konsumen. Produk ukir tembaga dan kuningan secara masal ratarata bersifat sederhana, ukuran kecil dan dibuat dengan jumlah terbatas sehubungan dengan terbatasnya permodalan. Produk ukir tembaga dan kuningan meliputi hiasan dinding/kayu penyangga, lampu, guci, mangkok, foto pahlawan, patung, kaligrafi dan produk ukir lainnya.Kemudian untuk produk pesanan, Industri Ukir Tembaga dan Kuningan Zazen Art Galeria sudah berani menerima pesanan produk dengan berbagai bentuk dan ornamen. Untuk beberapa produk dengan desain komplek, Industri Ukir Tembaga dan Kuningan Zazen Art Galeria sebenarnya masih terbatas dalam desain produk sehubungan dengan keterbatasan peralatan produksi (Muzazen, 2016). Namun dukungan industri tembaga dan kuningan lain yang tergabung dalam paguyuban industri tembaga dan kuningan memberikan kemudahan dan bantuan dalam inovasi, pengerjaan dan finishing produk.

Kualitas dan pengadaan bahan baku plat dan pipa baik tembaga maupun kuningan yang baik menjadi faktor penting dalam proses produksi produk ukir tembaga dan kuningan. Kondisi bahan baku yang diprioritaskan adalah yang masih baru, bersih dan tidak cacat. Persyaratan ini dimaksudkan untuk menjaga kualitas produksi. Kemudian bahan baku juga tidak boleh ada coran/tempaan. Selanjutnya untuk mendapatkan produk/barang yang baik, bahan baku kadang dicampur dengan unsur paduan yang sesuai dengan pesanan konsumen. Untuk produk-produk tembaga dengan tingkat desain yang rumit dan nilai jual tinggi, bahan baku baik plat atau pipa untuk sementara lebih banyak memakai bahan baku buatan Jepang dan Australia. Mereka mendapatkan bahan baku impor melalui importir nasional. Bahan baku tembaga lokal belum mampu untuk produk-produk dengan lekukan/desain dengan tingkat mulur tinggi. Namun untuk produk berbahan kuningan, bahan baku sudah banyak memakai bahan baku lokal. Untuk produksi masal, bahan baku hampir seluruhnya sudah memakai bahan baku lokal kualitas baik (ulet dan kuat).

Keberadaan industri ukir tembaga dan kuningan di kelurahan Mliwis Cepogo memberikan potensi yang besar terutama di bidang ekonomi, sosial, pendidikan dan lapangan kerja. Kelurahan Mliwis merupakan daerah/dataran tinggi dengan profil tanah tegalan dan terletak di bawah lereng gunung Merapi dan Margiono. Mata pencaharian utama di daerah Cepogo adalah petani tegalan, beternak dan penambang pasir. Pertumbuhan ekonomi pada saat awal relatif sulit. Munculnya industri kecil dan rumah tangga di sektor peternakan (ayam, sapi, kambing), perkebunan dan logam (kuningan dan tembaga) memberi lapangan kerja baru bagi masyarakat. Apalagi industri-industri rumah tangga rata-rata bersifat padat karya dan membutuhkan/menyerap banyak tenaga kerja. Geliat ekonomi rakyat di daerah Cepogo berjalan cukup baik sekarang ini. Kota kecil Cepogo yang menjadi jalur alternatif Solo Selo - Magelang (jalur wisata ke candi Borobudur) memberikan potensi/keuntungan tersendiri dalam mengangkat ekonomi rakyat Cepogo khususnya dan Boyolali umumnya. Dan di sisi lain, perkembangan industri ukir tembaga dan kuningan juga memberikan wahana atau sarana pendidikan bagi siswa dan 
Seno Darmanto, Indartono, Adi Nugroho

Aplikasi Mesin Pembangkit Kalor Las Lpg Untuk Potong, Penyambungan Dan Pembentukan

mahasiswa untuk meningkatkan ketrampilan baik manejemen dan proses produksi melalui program magang atau praktek kerja.

Industri ukir kuningan dan tembaga juga memberikan dukungan pada wisata alamdan agro di daerah lereng gunung Merapi dan Margiono khususnya wisata alam pegunungan Selo. Obyek wisata di lereng gunung Merapi sekarang tidak hanya wisata alam pegunungan Selo tetapi didukung oleh wisata agro berupa memetik langsung sayur dan buah, alam tambang (pasir dan batu) dan showroom produk ukir kuningan dan tembaga. Showroom-showroom produk ukir tembaga dan kuningan sekarang sudah mulai mendekati jalur utama Solo-Selo-Magelang untuk menarik dan meningkatkan pangsa pasar sekaligus untuk mendukung obyek wisata alam pegunungan Selo. Sehingga wisata domestik dan luar yang berkunjung ke Selo ataupun ke candi Borobudur namun melalui jalur/lewat Selo akan mempunyai obyek/tujuan wisata yang cukup beragam dan menarik di daerah Cepogo Boyolali.

Produk ukir dengan desain rumit dan ukuran relative besar masih menjadi kendala bagi industri ukir tembaga dan kuningan selevel industri kecil dan menengah di daerah Cepogo. Ada sekitar 10-an unit industri ukir tembaga dan kuningan di daerah Kelurahan Mliwis yang benar-benar telah beroperasi secara aktif. Sedangkan industri-industri ukir kecil (home industry) yang banyak beroperasi di Kelurahan Mliwis Cepogo rata-rata menyuplai komponen pendukung seperti bahan cetakan, penghalusan dan komponen (produk) ukuran kecil atau sederhana. Kesulitan/kendala utama industri dalam menghasilkan produk dengan desain yang rumit dan ukuran besar sebenarnya bukan pada penuangan ide/gagasan awal namun lebih banyak terletak pada proses pengerjaan (pembentukan). Bantuan pelatihan dari pemerintah daerah (dinas perindustrian) telah meningkatkan industriawan ukir tembaga dan kuningan dalam menggali inovasi hingga penuangan dalam bentuk gambar (sketsa) dan penentuan metode pengerjaan. Gagasan dan inovasi yang baru umumnya akan menemui kesulitan (berhenti) saat melakukan proses pembentukan di unit produksi. Proses pengerjaan produk yang sederhana dapat ditempa dengan peralatan tangan. Namun untuk desain yang rumit, proses pengerjaan perlu dilakukan dengan bantuan peralatan atau mesin. Proses pengerjaan produk dengan tingkat kesulitan yang rumit umumnya pada desain produk berbahan baik plat atau pipa (persegi atau lingkaran) yang ada profil lekukan atau belokan. Produk ukir tembaga dan kuningan dengan desain lekukan dan ukuran besar meliputi lampu gantung, kap (rumah, teras atau taman), guci ukuran besar, kaligrafi, stupa (masjid, candi,tempat ibadah), hiasan gapura dan produk hiasan luar.

Proses pengerjaan produk dengan profil lekukan melibatkan proses pengerolan, tekuk(Groover, 1996; Brown, 1998) dan proses pengelasan (Darius, 2005). Proses penekuk bahan plat atau bahan merupakan tahap pengerjaan awal bahan. Hasil pengerjaan penekukan biasanya menghasilkan kerutan dan tarikan disekitar tekukan bahan plat atau bahan dan biasanya diperbaiki dengan pengerjaan pengelasan. Untuk proses pengerjaan produk dengan profil lekukan dalam ukuran besar dikerjakan (disubkan) di industri besar. Proses pembentukan bahan dengan profil lekukan biasanya menghasilkan efek samping berupa kerutan di produk dan efek lebih lanjut bahan akan retak (Juvinall, 1967). Pengerjaan las untuk profil lekukan akan menghasil permukaan kasar dan kualitas produk akan menjadi getas (Darius, 2005). Prosespengelasanjugamembutuhkanbiayabaha $\mathrm{n}$ las (oksigen dan asitelin) cukup besar. Pengerjaan di industri besar akan menaikkan biaya produksi berupa biaya pengerjaan dan transport. Kenaikan biaya produksi dapat mencapai $30 \%$ - $35 \%$ per unit dari biaya keseluruhan ketika proses pengerjaan terpaksa (harus) dilakukan (disubkan) ke industri lain. 
Seno Darmanto, Indartono, Adi Nugroho

Aplikasi Mesin Pembangkit Kalor Las Lpg Untuk Potong, Penyambungan Dan Pembentukan

Secara keseluruhan, produk akhir akan menjadi lebih mahal dan kurang kompetitif. Penyempurnaan peralatan unit-unit produksi perlu dilakukan secara bertahap untuk memperbaiki dan meningkatkan proses produksi dan daya saing industri ukir tembaga dan kuningan.

Industri ukir tembaga dan kuningan Industri Ukir Tembaga dan KuninganZazen Art Galeria merupakan industri yang mulai berbenah dan berkembang menuju industri dengan menejemen yang baik dan bersaing secara kompetitif. Penyempurnaan unit-unit produksi meliputi metode pembukuan, proposal pengajuan/pengadaan bahan, peralatan unit produksi dan metode pemasaran yang baik dilakukan melalui pelatihan dan peningkatan modal usaha. Perhatian pemerintah daerah dan instansi terkait berupa pelatihan dan bantuan permodalan menjadi motivasi industri ukir tembaga dan kuningan terutama Industri Ukir Tembaga dan Kuningan Zazen Art Galeria untuk menggali inovasi dan meningkatkan proses produksi. Keterbukaan dan kebutuhan akan pembimbingan dalam pembenahan usaha Industri Ukir Tembaga dan Kuningan Zazen Art Galeria menjadi faktor utama dimulainya hubungan kerja yang direncanakan dan sedianya akan dilakukan dalam program Iptek untuk masyarakat ini.

Produk dengan desain rumit dan ukuran relative besar masih menjadi kendala bagi industri ukir tembaga dan kuningan selevel industri kecil dan menengah di daerah Cepogo. Ada sekitar 10-an unit usaha ukir tembaga dan kuningan di daerah Kelurahan Mliwis yang benar-benar telah beroperasi secara aktif. Sedangkan industri-industri ukir kecil (home industry) yang banyak beroperasi di Kelurahan Mliwis Cepogo rata-rata menyuplai komponen pendukung seperti bahan cetakan, penghalusan dan komponen (produk) ukuran kecil atau sederhana. Kesulitan/kendala utama industri dalam menghasilkan produk dengan desain yang rumit dan ukuran besar sebenarnya bukan pada penuangan ide/gagasan awal namun lebih banyak terletak pada proses pengerjaan (pembentukan). Proses pembentukan bahan dengan profil rumit (profil melengkung) biasanya menghasilkan efek samping berupa kerutan di produk dan efek lebih lanjut produk akan retak. Bantuan pelatihan dari pemerintah daerah (dinas perindustrian) telah meningkatkan industriawan ukir tembaga dan kuningan dalam menggali inovasi hingga penuangan dalam bentuk gambar (sketsa) dan penentuan metode pengerjaan. Gagasan dan inovasi yang baru umumnya akan menemui kesulitan (berhenti) saat melakukan proses pembentukan di unit produksi. Proses pengerjaan produk dengan tingkat kesulitan yang rumit umumnya pada desain produk berbahan baik plat atau pipa (persegi atau lingkaran) yang ada profil lekukan atau belokan. Produk ukir tembaga dan kuningan dengan desain lekukan dan ukuran besar meliputi lampu gantung, kap (rumah, teras atau taman), guci ukuran besar, kaligrafi, stupa (masjid, candi,tempat ibadah), hiasan gapura dan produk hiasan luar.

Proses pengerjaan produk dengan profil lekukan dan ukuran besar secara umum dikerjakan melalui beberapa tahap meliputi pengerolan, pembentukan, pengelasan dan penyelesaian akhir (Muzazen, 2016). Pengerolan merupakan proses pengerjaan bahan yang diarahkan pada pengurangan ketebalan yang disertai dengan peningkatan kekuatan akibat regangan yang diterima selama pengerolan. Adanya penurunan ketebalan, bahan akan lebih mudah dibentuk ke profil yang diinginkan (Vlack,1989). Jenisjenis ornamen di permukaan bahan juga dapat dimunculkan secara paksa melalui proses pengerolan. Bentuk permukaan rol silinder akan mempengaruhi permukaan bahan yang dikenai proses pengerolan. Dalam praktek di lapangan atau industri, mekanisme peralatan pengerolan terdiri dari roll yang berputar, transmisi daya, motor penggerak (Khurmi, 1980) dan panel atau pengatur gerakan roll. 
Seno Darmanto, Indartono, Adi Nugroho

Aplikasi Mesin Pembangkit Kalor Las Lpg Untuk Potong, Penyambungan Dan Pembentukan

Selanjutnya untuk bentuk produk pengerolan tertentu, bentuk roll dapat dimodifikasi sesuai dengan bentuk benda yang akan dirol dan tujuan pengerolan.

Proses pembentukan merupakan tahap pengerjaan ke bentuk benda jadi. Untuk benda atau produk dengan bentuk beraturan seperti balok, kubus, silinder, prisma dan bentuk teratur lain tentu akan lebih mudah dalam proses pembentukan baik dalam penyambungan dan pengerjaan akhir. Untuk produk atau benda dengan bentuk alami (natural) yang ada di alam cenderung tidak beraturan meliputi profil binatang, profil tumbuhan, profil manuasia dan profil aerodinamis benda bergerak. Untuk produk ukir tembaga dan kuningan dengan profil tidak beraturan, ada tambahan proses pengerjaan yakni pengelasan/pelapisan dan penyelesaian akhir. Pelapisan produk berbahan dasar logam lebih banyak dilakukan dengan mekanisme pengelasan.Dengan pengelasan bahan pelapis dengan ukuran yang tepat diharapkan dapat menempel kuat di bagian yang perlu diberi tambahan ketebalan. Di sisi lain, sehubungan dengan keterbatasan teknologi pelapisan dengan pengelasan, ada kelebihan bahan dalam proses pelapisan yang perlu dibersihkan dan disesuaikan dengan ukuran atau dimensi di tahap pengerjaan selanjutnya.Tujuan kegiatan ini adalah modifikasi instalasi mesin pembangkit kalor jenis pengelasan LPG untukpengerjaan potong, menyambung dan membentuk lengkung pada pipa dan plat.

\section{METODE KEGIATAN}

Ada beberapa mesin pembangkit kalor yang diaplikasikanmeliputi tungku, nyala api las dan nyala api gas LPG. Desain tungku merupakan desain tungku lengkap yang terdiri dari dari ruang bakar, lubang api (lebih dari 1 lubang), lubang udara dan udara paksa, ruang abu dan cerobong. Lubang api didesain 2- 3 lubang dengan sistem buka dan tutup. Udara paksa dibangkitkan dari tenaga blower/fan
udara.Selain dengan tungku pemanas, pembangkitan kalor dapat menggunakan nyala api gas LPG dan nyala las. Pengelasan LPG padaprinsipnyaterdiridari tabung oksigen dan katup pengaturan (regulator oksigen), tabung LPG dan katup pengaturan (regulator LPG), selangan distribusi gas (oksigen dan gas LPG), alat ukur tekanan dan injektor nyala las.Untuk pemanasan plat dengan ketebalan di bawah 1 $\mathrm{mm}$ dapat dilakukan dengan nyala api gas LPG. Nyala api gas LPG dapat dibangkitkan melalui proses pembakaran gas LPG seperti pembangkitan nyala api kompor untuk masak. Proses pemanasan dengan blander pemanas LPG ditunjukkan pada Gambar 3. Ada beberapa keuntungan proses pemanasan plat dengan teknik ini meliputi terpenuhinya fungsi pemanasan, pemanasan dapat dilakukan ditempat yang berbeda/berpindah, ramah lingkungan dan pekerja dan biaya lebih murah.

\section{HASIL DAN PEMBAHASAN}

Realisasi pembuatan tungku berbahan bakar arang yang terdiri dari dari ruang bakar, lubang api dengan 1 (satu) lubang, pipa udara dan blower biasanya diaplikasikan untuk pemanasan plat tebal dengan ketebalan di atas $1 \mathrm{~mm}$. Lubang api dibuat hanya 1 (satu) lubang yang berarti abu, cerobong asap dan api berada di satu tempat. Asap akan lengsung naik keatas lubang api. Sedangkan abu akan turun ke bawah. Namun karena aliran udara pembakaran dengan udara paksa maka sebagian besar abu akan ikut terbang ke atas bersama asap. Udara paksa dibangkitkan dari tenaga blower/fan udara. 
Seno Darmanto, Indartono, Adi Nugroho

Aplikasi Mesin Pembangkit Kalor Las Lpg Untuk Potong, Penyambungan Dan Pembentukan
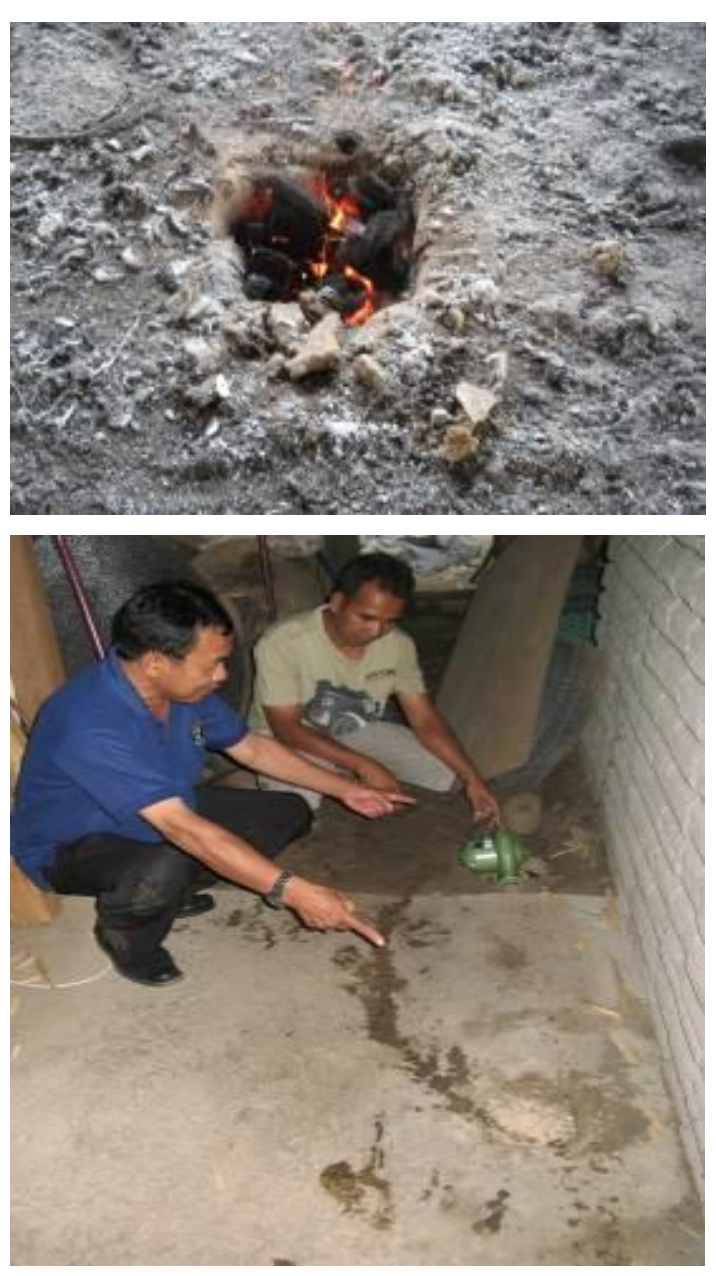

Gambar 1. Realisasi pembuatan tungku di mitra

Meskipun tungku pemanas dengan 1 lubang mempunyai banyak keuntungan meliputi fungsi, waktu dan pembiayaan untuk pembuatan, itu sebenarnya mempunyai banyak kelemahan juga meliputi lingkungan sekitar kotor, cenderung tidak ramah bagi pekerja (pekerja perlu memakai masker) dan kerugian kalor tinggi. Peningkatan efisiensi tungku dengan 1 lubang nyala api dapat ditingkatkan dengan cara memodifikasi volume lubang bahan bakar dan pengaturan debit aliran blower. Untuk pengerjaan pemanasan plat relatif kecil, pemilihan volume lubang dapat menggunakan lubang kecil dan pengaturan kecepatan blower pada posisi sedang dan tinggi. Sedangkan untuk pengerjaan pemanasan plat relatif luas dan tebal, pemilihan volume lubang dapat menggunakan lubang besar dan pengaturan kecepatan blower pada posisi rendah dan sedang. Tungku pemanas di mitra Zazen Art Gallery di tunjukkan pada Gambar 1.

Pembangkitan kalor dengan menggunakan nyala api gas LPG dapat ditingkatkan efisiensinya dengan mengatur dimensi keluaran/blander/nosel injeksi nyala api.Analogi dengan tungku pemanas dengan mengatur volume bahan dan debit aliran udara, nyala api gas LPG yang dibangkitkan melalui proses pembakaran gas LPG dapat rekayasa dengan mengutur dimensi blander dan pengaturan aliran bahan bakar dengan regulator bahan bakar. Modifikasi blander pemanas dilakukan dengan mengatur dimensi luasannya. Ada beberapa spesifikasi blander pemanas dari $25 \mathrm{~mm}$ sampai dengan $100 \mathrm{~mm}$.

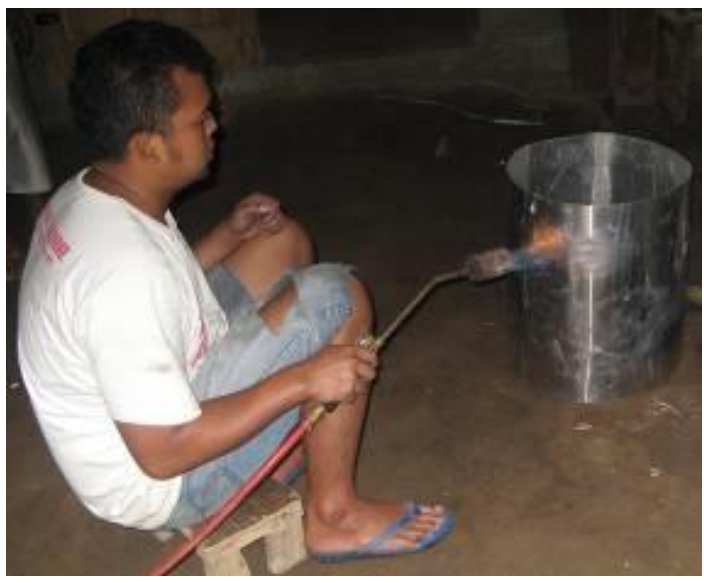

Gambar 2. Tahapan pemanasan plat dengan nyala api LPG

Pembangkitan kalor dengan bahan bakar LPG dapat juga dilakukan dengan teknik pengelasan. Hampir sama dengan pengelasan asetilin, pengelasan LPG menggunakan beberapa komponen meliputi tabungoksigen dan katuppengaturan (regulator oksigen), tabung LPG dan katuppengaturan (regulator 
Seno Darmanto, Indartono, Adi Nugroho

Aplikasi Mesin Pembangkit Kalor Las Lpg Untuk Potong, Penyambungan Dan Pembentukan

LPG), selangandistribusi gas (oksigen dan gas LPG), alatukurtekanan dan injektornyala las (Rai, 2016; Furgon, 2011). Pengelasan LPG di industri ukir Cepogo Boyolali dapat diaplikasi di beberapa pengerjaan logam meliputi pemanasan, pembersihan, pemotongan, penyambungan. Untuk aplikasi pemanasan plat bahan sebelum diukir atau dibentuk motif, capaian tingkat pemanasan plat mendekati atau bahkan melebihi tungku pemanas arang. Selanjutnya aplikasi las LPG untuk pembersihan biasanya dignakan untuk menghilangkan lapisan pewarna, lapisan cat, jabung dan pengotor lain. Aplikasi las LPG untuk pemotongan dan penyambungan dapat diplikasikan untuk plat dengan ketebalan rendah di bawah 0,6 $\mathrm{mm}$.Analogi pengelasan LPG, pengelasan asetilin menggunakan beberapa komponen meliputi tabungoksigen dan katup pengaturan (regulator oksigen), tabung asetilin dan katuppengaturan (regulator asetilin), selangan distribusi gas (oksigen dan gas LPG), alat ukurtekanan dan injektornyala las. Pengelasan asetilin pada prinsipnya untuk proses pengerjaan logam dengan kebutuhan kalor tinggi dan spesifikasi bahan yang tinggi.

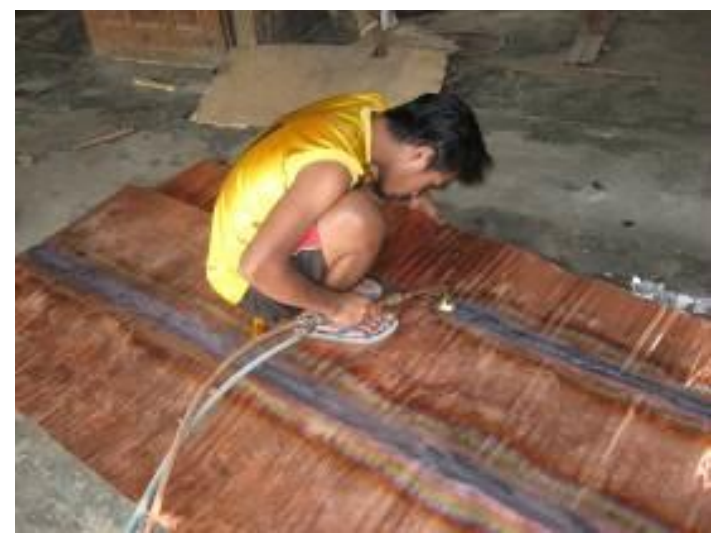

Gambar 3. Pengelasan dengan LPG

Dalam praktek pengelasan sehari-hari di industri tembaga dan kuningan, instalasi las asetelin dimodifikasi dengan mengganti tabung asetelin dengan tabung gas LPG. Ada beberapa pertimbangan industri atau Zazen Art
Galeri menggunakan gas LPG meliputi harga murah, tersedia secara luas, distributor gas dekat dan kemampuan pengelasan yang bersaing terhadap las asetelin. Harga tabung LPG bekas berkapasitas $12 \mathrm{~kg}$ berharga $\mathrm{Rp}$ 250.000,-_ Rp. 500.000,- di pasaran dan harga akan lebih murah dengan menggunakan tabung LPG bersubsidi berkapasitas $3 \mathrm{~kg}$. Dalam pengamatan dan analisa pengelasan di industri, bahan tembaga dan atau kuningan mampu dipotong dan disambung secara sempurna dengan las LPG.

\section{SIMPULAN}

Realisasi pembuatan tungku berbahan bakar arang yang terdiri dari dari ruang bakar, lubang api dengan 1 (satu) lubang, pipa udara dan blower biasanya diaplikasikan untuk pemanasan plat tebal dengan ketebalan di atas $1 \mathrm{~mm}$. Pembangkitan kalor dengan menggunakan nyala api gas LPG dapat ditingkatkan efisiensinya dengan mengatur dimensi keluaran nyala api yang mempunyai dimensi dari 25 mm - 100 mm. Pembangkitan kalor berbahan bakar LPG dengan teknik pengelasan menggunakan beberapa komponen meliputi tabung oksigen dan katup pengaturan (regulator oksigen), tabung LPG dan katup pengaturan (regulator LPG), selang distribusi gas (oksigen dan gas LPG), alat ukur tekanan dan injektor nyala las. Analogi pengelasan LPG, pengelasan asetilin menggunakan beberapa komponen meliputi tabung oksigen dan katup pengaturan (regulator oksigen), tabung asetilin dan katup pengaturan (regulator asetilin), selang distribusi gas (oksigen dan gas LPG), alat ukur tekanan dan injektor nyala las. Pengelasan asetilin pada prinsipnya untuk proses pengerjaan logam dengan kebutuhan kalor tinggi dan spesifikasi bahan yang tinggi

\section{UCAPAN TERIMA KASIH}


Seno Darmanto, Indartono, Adi Nugroho

Aplikasi Mesin Pembangkit Kalor Las Lpg Untuk Potong, Penyambungan Dan Pembentukan

Kami mengucapkan terima kasih kepada semua pihak yang telah terlibat dalam pengabdian ini terutama mahasiswa, teknisi dan PSD III Teknik Mesin Mesin, Sekolah Vokasi Undip. Terima kasih kepada DRPM melalui Skim Iptek bagi Masyrakat yang telah mendanai kegiatan pengabdian melalui Direktorat Riset dan Pengabdian kepada Masyarakat Direktorat Jenderal Penguatan Riset dan Pengembangan Kementerian Riset Teknologi dan Pendidikan TinggiSesuai dengan Surat Perjanjian Penugasan Program Pengabdian kepada MasyarakatNomor: 007/SP2H/PPM/DRPM/V/2017, tanggal 5 Mei 2017

\section{DAFTAR PUSTAKA}

Brown, J, (1998). Advanced Machining Tecnology Handbook. McGrawHill

Darius, A. (2005). Pengelasan. Proses Produksi, Jakarta : Universitas Darma Persada

Furqon, R.S. (2011). Pengujian dan Analisis Sambungan Las Tabung Gas LPG Kapasitas3 kg. Tugas Akhir, Jurusan Teknik Mesin Fakultas Teknik Universitas Pasundan Bandung.

Groover, M.P. (1996). Fundamentals of Modern Manufacturing: Material, Process and Systems. PrenticeHall.Inc, Asimon \& Schulter Company.

Juvinall, R.C. (1967). Stress, Strain and Strength. New York : McGrawWill Book Company

Khurmi, R.S. (1980). A Text Book Machine Design. New Delhi : Eurasia PublisingHouse.Ltd.
Muzazen, (2016). Industri Ukir Tembaga dan Kuningan CV Zazen Art Galeria di Cepogo. Survey langsung di $C V$ Zazen Art Galeria Cepogo Boyolali.

Rai, I., (2016). RancangBangunAlat Bantu Las Tabung LPG $3 \mathrm{Kg}$ (Perhitungan Waktu Permesinan dan Biaya Produksi). Tugas Akhir, Politeknik Negeri Sriwijaya Jurusan Teknik Mesin Palembang.

Vlack, L.H.V. dan Djaprie, S. (1989). Ilmu dan Teknologi Bahan. Terjemahan, Jakarta : Erlangga 